\title{
KALBA
}

\section{EUROPOS SAMPRATA \\ LIETUVIO SĄMONĖJE}

\author{
Dr. Marius SMEtona
}

Vilniaus universitetas

Vilnius University

Universiteto g. 3, LT-01513 Vilnius

El.paštasmarius.smetona@gmail.com

\section{Santrauka}

Straipsnyje kognityvines definicijos metodu atliekama EUROPOS koncepto analizè. Iš jos išryškeija, kas lietuviams yra Europa, su kuo ji asocijuojasi, kokia galima žodžio „Europa“ kognityviné definicija. Ji formuluojama iš šiandienio jaunimo apklausose pateiktu minčiu apie Europa ir atskiru diskursų analizés, išryškëjusiu semu bendrybiu ir skirtumų.

Reikšminiai žodžiai: kognityvinè definicija; diskursas; konceptas; Europa; anketa; kultūra.

\section{Ivadas}

Šių dienų lingvistika nebeapsiriboja siauros srities tyrinèjimais, vis dažniau kalbama apie tarpdalykinius ryšius, kelių sričių metodų dermę. Pirmiausia tai taikoma vienai iš naujausių kalbos mokslo krypčių - etnolingvistikai, kitaip dar vadinamai antropologine ar kultūrine lingvistika. Jos tyrinėjimų sritị sudaro kalbos santykis su tautos istorija, visuomeniniu gyvenimu ir kultūra. Kalbos ir kultūros santykiui, kultūriniams kalbos aspektams, kalboje užkoduotai kultūrai atskleisti šiuo atveju atiten- 
ka išskirtinis dėmesys. Šia - kalbos santykio su kultūra - problematika, šaknimis siekiančia XIX a. Wilhelmo von Humboldto kalbos filosofiją, pastaraisiais dešimtmečiais imta domėtis itin aktyviai. Etnolingvistai pasitelkia kognityvistų metodus ir išplečia kalbos reikšmę visuomenės gyvenime - kalbos turinys sutapatinamas su visu esamu sąmonės turiniu. Savo tyrinejjimų objektu jie įvardija kalbètojų sąmonèje egzistuojančias sąvokas - konceptus kaip žmogaus patyrimo ir visos psichomotorinès veiklos rezultatą. Kognityvistai teigia, kad kalbos turinys - tai tam tikru atžvilgiu žmogaus ir pasaulio, tikrovès susidūrimo rezultatas, žmogaus jutiminių bei emocinių pasaulio patyrimų ir jų apdorojimo sąmonèje visuma. Etnolingvistai nueina dar toliau - pasiremdami kalbos faktais jie rekonstruoja žmonių pasaulèvaizdị kaip tam tikro silpniau ar stipriau kalboje išreikšto nuomonių komplekso apie pasaulio, esančio už kalbos ribų, objektų požymius ir egzistavimo būdą, įtvirtintą žodžių reikšmėse. Šiuo požiūriu kalbos pasaulèvaizdis yra fiksuota visuma santykių, išreikštų teksto kalbine forma ir kylančių iš nekalbinio pasaulio pažinimo $^{1}$. Etnolingvistai ypač pabrèžia kultūros aspektą. Kalbėdamas apie etnolingvistikos mokslo siekius, lenkų etnolingvistinès mokyklos pradininkas Jerzy is Bartmińskis orientuojasi ị kalbos ne tik kaip visuomenès komunikaciją lemiančias priemonès, bet kaip pačios kultūros sudètinès dalies ištyrimą. Šią kultūros dalị kalbininkas ịvardija kaip neịprastą, nes ji ne tik sukaupia kultūros kaip visumos esminius požymius, bet ir išryškina tai kultūrai būdingus daiktų ir reiškinių konceptualizacijos ir kategorizacijos būdus, egzistuojančias vertinimų sistemas, matymo taškus, visuomenejje ịtvirtintą poziciją pasaulio atžvilgiư ${ }^{2}$. Kalba ne tiek daro ịtaką pasaulio pažinimui, kiek atskleidžia tam tikros kalbinès bendruomenès pasaulio ir kultūros suvokimo būdą. Be tradicinių etnolingvistikos mokslo aiškinimų, lietuvių etnolingvistikoje atsiranda tau-

1 Bartmiński, J., Tokarski, R. Językowy obraz świata i spójność tekstu. Teoria tekstu. Wrocław, 1986, p. 72.

2 Bartmiński, J. Czym zajmuje sie etnolingwistyka. Akcent. Wrocław, 1986, Nr. 4(26), p. 18. 
tos mentaliteto kalboje motyvas. Tokị etnolingvistikos uždavinị lietuvių kalbininkas Aloyzas Gudavičius nurodo savo knygoje „Etnolingvistika“. Pasak autoriaus, etnolingvistika turi parodyti, kaip kalboje atrodo tauta - jos požiūris i pasauli, to pasaulio supratimas ir vertinimas, jos kultūra pačia plačiausia prasme, įskaitant visą sukurtą artefaktų pasaulį, tradicijas ir kasdienès veiklos bei elgesio standartus. Tautos atspindys kalboje turi apimti ir tai, kas vadinama mentalitetu, tautine psichologija. Etnolingvistikos mokslo objektu autorius ịvardija tautą kalboje, tautos mentalinio ir dvasinio gyvenimo atspindi kalboje $\mathrm{e}^{3}$.

Kalbos pasaulèvaizdis apima nuomonių apie žmogų ir pasaulị kompleksą, išskaitomą iš skirtingų kalbinių duomenų, o nuomonès labiau ar mažiau yra priklausomos nuo tautos ar individo pripažistamų ir puoselëjamų vertybių. Tokiu būdu vertybės tampa tuo veiksniu, kuris daro didelę ịtaką pasaulio vizijai (vadinasi, - ir pasaulio vaizdui), kuriamai subjekto, patiriančio ir konceptualizuojančio tikrovę ${ }^{4}$. Būtent jos integruoja tradicijos ir visuomenès pripažintus pasaulio vaizdo elementus, kuria kalbos vartotojų kultūrinę ir socialinę tapatybę ${ }^{5}$, o mums iš viso leidžia kalbèti apie tautos dvasinę kultūrą. Nepriklausomai nuo savo intensyvumo, vertybès visuomet randa vietą kalboje ir už kalbos ribų. Jos yra neatsiejama dalis to turinio, kurị bandoma išgauti iš turimos kalbinès medžiagos. Rekonstruodami tautos, tam tikros kalbinès bendruomenès pasaulio ir savo vietos jame suvokimo būdą, turintị savo išraišką kalboje, kartu rekonstruojame ir jos vertybių sistemą.

Vertybių sistemoje kaip vienas iš komponentų egzistuoja tautos susivokimas ją supančiame pasaulyje, identifikacija su jai artima kultūra, geografine vieta. Šis straipsnis susijęs su lietuviška Europos samprata.

3 Gudavičius, A. Etnolingvistika. Šiauliai, 2009.

4 Daugiau apie sąmonės aksiologinius parametrus žr. Bartmiński, J. Etnolingwistyka. Lublin, 1994, t. 6, p. 29-51.

5 Bartmiński, J. Jezykowe podstawy obrazu świata. Lublin, 2007, p. 133. 
Lietuvoje nauju kognityvinès definicijos metodu ${ }^{6}$ atlikta EUROPOS koncepto analizė atskleidžia ne tik lietuvių suvokimą, kas jiems yra Europa, bet ir leidžia suformuluoti kognityvinę definiciją, kokios iki šiol nebuvo pateikta nè viename leksikografiniame šaltinyje. Politikams šis straipsnis turètų būti itin ịdomus ir svarbus, juk gana dažnai viešai kalbama apie Europą net nesusimąstant, ką ji iš tiesų reiškia visuomenei, kokią reikšmę ji turi lietuviškai tapatybei. Be to, turètų būti įdomūs studentų apklausos rezultatai, nes šiandieniai studentai lems Lietuvos ateitị, tad $\mathfrak{i}$ jų mintis būtina ịsiklausyti formuojant valstybès politiką.

\section{Problemos ištirtumas ir kultūrinis kontekstas}

Konkrečių kalbinių tyrinèjimų apie Europos suvokimą nesama. Paminèti galima nebent Vidos Rudaitienès straipsnị, kuriame aptariamas nelietuviškos kilmès prepozicinio dèmens euro- vartojimas. Daugiau galima rasti filosofinio ir kultūrinio, politologinio pjūvio tyrinejjimų. Kaip naujausias minètina Nerijos Putinaitès knyga „Trys lietuviškos Europos. Tauta, Europa, ES dabartinëje tapatybejje“. Bet nè viena iš tokio pobūdžio knygų ar straipsnių neatsako ị klausimą, kas yra Europa lietuviui. Dèl šios priežasties reikia naujo tyrinejjimo metodo. Iš pradžių tikslingiausia aprašyti, kokia kultūrinè ir istorinè situacija galèjo nulemti Europos suvokimo lietuvių pasąmonejje raidą. Galima teigti, kad kituose skyriuose nagrinëjamuose pavyzdžiuose ši raidos specifika ir atsispindi.

Pradèti reikètų nuo baltų genčių ir Europos santykio. Baltų pasaulèžiūroje esama daug panašumų su Skandinavijos mitologija, yra karinių veiksmų pėdsakų, liudijančių apie tarpusavio kontaktus. Pirmaisiais mūsų eros amžiais baltai patyrè jau ir antikinès civilizacijos poveiki per

6 Šis straipsnis yra parengtas pagal tarptautiniam projektui EUROJOS (Grant EUROJOS, pt. Metody analizy językowego obrazu świata w kontekście badań porównawczych. Grant NPRH nr 0132/NPRH2/H12/81/2012, na lata 20122015. Instytut Slawistyki PAN, Warszawa.) rengtą EUROPOS koncepto analizę, tad laikomasi Liublino etnolingvistų mokyklos kognityvinès definicijos sampratos ir koncepto analizès metodologijos. 
prekybą su Romos imperija, žinoma, per tarpininkus. Kraustantis tautoms, baltų gentims po truputị jungiantis ị vienokias ar kitokias sąjungas ir užsimezgant santykiams su slavais, ankstyvaisiais viduramžiais baltai jau tiesiogiai susidūrè su lotyniškąja Vakarų Europos ir bizantiškąja Rytų Europos civilizacijomis ${ }^{7}$. Dèl geografinès padèties Lietuvai buvo lemta patirti įvairių kultūrų itaką ir atsidurti jų sankryžoje.

Konkrečiau apie lietuvių požiūrị i Europą galima kalbėti tik tada, kai atsiranda rašytiniai šaltiniai, todèl tam tikros opozicijos tarp Europos, tiksliau Vakarų valstybių ir Lietuvos, paliudijimų esama dar iki Lietuvos krikšto. Pagrindinè opozicija yra religija ir kultūra. Pirmieji lietuvių žingsniai europietiškumo link buvo karaliaus Mindaugo karūnacija. Manoma, kad šis valdovas pažino „svetimą, priešišką ir paslaptingą Europos civilizacijos pasaulị ir „išmoko mąstyti kaip Vidurio Europos monarchas $^{\text {"s }}$. Žinoma, net ir po Mindaugo karūnavimo Vakarai išliko priešai ne tik karine, bet ir religine prasme, nes valstybè nebuvo visuotinai pakrikštyta, pasąmonèje buvo įsivyravusi priešprieša jie ir mes ${ }^{9}$. Didesnè Lietuvos integracija prasideda Lietuvos didžiajam kunigaikščiui Gediminui pradejjus kviesti amatininkus, pirklius, vienuolius iš Vakarų Europos ị Vilnių, greičiausiai ne tik dèl ekonominių, bet ir kultūrinių paskatų. Atsikraustę žmonès atsivežè ir savo pasaulio suvokimą, be to, Lietuvai sparčiai plečiantis ị slavų žemes, neabejotinai susidurta ir su slavų tautų požiūriu ị Europos šalis. LDK apskritai pasižymėjo tolerancija ¡̇vairioms tautoms, jų tradicijoms, religijoms - didelejje teritorijoje gyveno skirtingai kalbantys ịvairių konfesijų žmonès, svarbiausia - jie gyveno taikiai $^{10}$, net suvokdami savo skirtingumą buvo toleruojami ir toleravo

7 Gudavičius, E. Lietuvos istorija. Vilnius, 1999.

8 Gudavičius, E. Tautinès lietuvių savimonès lygis XIV a. pabaigoje. Lietuvos Didžiosios Kunigaikštijos tradicija ir paveldo ,,dalybos “. Vilnius, 2008.

9 Ten pat.

${ }^{10}$ Augustyniak, U. Wielokulturowość Wielkiego Księstwa Litewskiego i idea tolerancji, a praktyka stosunków międzywyznaniowych w XVI-XVIII. Lietuvos Didžiosios Kunigaikštijos tradicija ir tautiniai naratyvai. Vilnius, 2009. 
kitus $^{11}$, skleidè savo kultūrą ${ }^{12}$. Daugiakultūrè Lietuva tarsi atspindèjo šiandien Europoje skleidžiamą idèją toleruoti ir gerbti kitus, kartu išlaikant savo valstybingumą ir tautų identitetą. Iš esmès netgi galima teigti, kad lietuviai tapo europiečiais anksčiau, nei patys europiečiai suprato, kad jie yra europiečiai.

Vis dèlto religinè priešprieša tarp Lietuvos ir Vakarų Europos išliko iki pat Lietuvos krikšto, nes pagoniška Lietuva buvo nuolat puolama Kryžiuočių ordino. Po 1387 m. pakrikštytai Lietuvai atsivèrẻ kelias palaikyti diplomatiškus santykius su Vakarų Europa, o jos kultūra pradejjo daryti ịtaką Lietuvai. Ši ịtaka ypač sustiprèjo sukūrus Abiejų Tautų Respubliką, kurios karaliais ar karalių žmonomis tapo žinomų Europos šalių giminių atstovai. Atvykdami jie atsiveždavo savo kultūrą, mokslo suvokimą, teisès žinias, o svarbiausia - filosofinès minties sklaidą, kuri leido plisti reformacijai Lietuvoje. Toks kultūrų susiliejimas paskatino LDK kilminguosius sekti Vakarų Europa ir pritaikius tai, kas geriausia, pradèti leisti knygas, parašyti 1468 m. Teisyną, išleisti Statutus (taip Lietuva ir Europa supanašèjo ir teisiniu požiūriu) ${ }^{13}$, domètis mokslu, remti kultūrą.

Lietuvai sunkus, bet savotiškai ịdomus buvo laikotarpis po Abiejų Tautų Respublikos trečiojo padalijimo. LDK atsidūrus carinès Rusijos okupacijoje ir po sukilimų sunaikinus didelę dalị didikų, buvo mėginama vykdyti rusifikaciją, net uždrausta spauda. Bet sekdami idejomis, kurias paskatino Prancūzijos revoliucija, ir Europoje kylančia tautos laisvès dvasia, lietuviai, remdamiesi Rytų ir Vidurio Europos pavyzdžiu, pradejo ugdyti tautos šviesuomenę iš žemdirbių. Lietuvių kultūros veikèjai - Šatrijos Ragana, Jonas Biliūnas, Maironis - buvo atviri visoms politinèms ir

11 Bairašauskaitè, T. Vietinis komponentas sociokultūrinès tapatybès konstrukcijose (istoriografinis kontekstas). Lietuvos Didžiosios Kunigaikštijos tradicija ir tautiniai naratyvai. Vilnius, 2009.

12 Temčinas, S. Lietuvos Didžiosios Kunigaikštijos rusėniškoji literatūra kaip kultūrinès integracijos modelis. Lietuvos Didžiosios Kunigaikštijos tradicija ir tautiniai naratyvai. Vilnius, 2009.

13 Jovaišas, A. Literatūra rusėnų kalba. Lietuvių literatūros istorija XIII-XVIII amžiuje. Vilnius, 2003. 
kultūrinėms Europos srovėms ${ }^{14}$, nors ir jie vis pabrèždavo, kad Lietuva skiriasi nuo likusios Europos, bet turinti siekti tų pačių idealų.

Didelè dalis išsilavinusių tarpukario Lietuvos žmonių mokslus baigė Vakarų Europos universitetuose, iš kur parsivežè naujų idèjų ir pritaikè jas Lietuvoje. Po Sovietų Sąjungos okupacijos ir vykdytų represijų bei didelès propagandos sklaidos, stengtasi naikinti viską, kas buvo nors kiek europietiška, ypač laisvès idèją ${ }^{15}$. Propagandai pasidavė ir kultūros veikejjai, kurie Vakarų Europą pradejjo vaizduoti neigiamai. Kaip ryškiausią pavyzdi galima pateikti dabar jau prieštaringai vertinamą neoromantikę poetę Salomėją Nèrị ir jos eilèraščio „Lietuvai“ ištrauką: „Iš negandingų vakarų / Audrų perkūnijų prikrauti / Lingavo debesų laivai“. Šiame eilèraštyje iškyla Vakarų kaip priešo, karo motyvas.

\section{Leksikografinių šaltinių apžvalga}

Lietuvių kalbos sisteminiuose žodynuose Europos apibrèžimo nėra, tačiau gana didelè įvairių išvestinių formų gausa. Daugiausia derivatų pateikiama žodyne „Eurovoc“. Europos apibrèžimo ar bent jau apibūdinimo reikètų ieškoti geografijos atlasuose ir žinynuose ar mitologijos enciklopedijose, tačiau čia būtų tik žemyno, teritorijos ar mitologinio personažo apibūdinimas. Tokia situacija greičiausiai rodo, kad pati sąvoka yra gana nauja ir dabar vartojama vietoj senojo žemyno, krikščioniškojo pasaulio (galbūt viduramžiško suvokimo reliktas), Vakarų Europos, Vidurio Europos, Rytų Europos ir pan. ịvardijimų.

$\operatorname{Euro}(p)$ lietuvių kalboje gali atlikti kelias funkcijas: tai gali būti nelietuviškos kilmės prepozicinis dėmuo ar šaknis. Lietuvių kalbos žodyne (LKŽ) pateikiami tokie žodžiai su šaknimi europ: europèti, sueuropèti, eu-

${ }^{14}$ Survilaitè, J. Atsirémus i platų Europos žemèlapị. 2014. Prieiga per internetą: www. bernardinai.lt.

15 Potašenko, G. Istorijos kultūra šiuolaikinėje Lietuvoje: daugiakultūriškumo samprata visuomenejje ir Lietuvos Didžiosios Kunigaikštijos tyrimuose. Lietuvos Didžiosios Kunigaikštijos tradicija ir tautiniai naratyvai. Vilnius, 2009. 
ropietis, europietiškas, europietiškai, europinis, europiškas, europiškai. Pavyzdžiai tik patvirtina mintị, kad šaknis europ yra gana nauja, nes žodžių yra nedaug, priesagų vartojama negausiai: - $\dot{e} t i$, -ietis, -iškas, -inis, o lietuvių kalboje jų yra daugiau nei šeši šimtai. Panašias priesagas galima rasti ir „Eurovoc“ žodyne, bet čia esama ir kitokių, pvz., -izmas: europeizmas.

Be jau minètos darybos, „Eurovoc“ žodyne nemažai atvejų, kai eurožodyje eina nelietuviškos kilmès prepoziciniu dėmeniu: eurodoleris, eurokomunizmas, eurokorpusas, eurokreditas, euroobligacija, eurorinka, euroraketa, euroskepticizmas, eurotinklas, eurotunelis, eurovaliuta. Idomu tai, kad šiuo atveju euro- lietuvių kalboje atsistoja ị vieną gretą su auto-, video-, audio-, aero- ir t. t. Kaip teigia V. Rudaitienè, euro- kaip prepozicinis dèmuo lietuvių kalboje pradètas vartoti palyginti neseniai ir jo atsiradimas labiausiai sietinas su integracija ị Europos Sąungą. Dažnai prepozicinis demuo euro- sudurtiniuose žodžiuose turi Europos Sąungos ar ryšio su Europos Sąunga leksinę reikšmę (Rudaitienė 2001, 99).

\section{Apklausų duomenų analizė}

Siekiant išsiaiškinti jaunimo požiūrị ị Europos sampratą, atliktos studentų apklausos. I projekte EUROJOS iškeltą klausimą „Kas jums yra tikroji Europa?"“ atsakinejo Vilniaus universiteto skirtingų fakultetų studentai. Humanitarinių mokslų atstovai sudarè 48 proc. visų apklaustų studentų, 52 proc. buvo gamtos ir tiksliųjų mokslų atstovai. Apklausas vykdyti padejo Vilniaus universiteto Studentų atstovybė. Iš viso nagrinèta 116 anketų ${ }^{16}$. Jose buvo stebima, kaip studentai apibūdina, suvokia Europą; žodžiai ar jų junginiai, laikantis projekto metodikos, suskirstyti ị grupes pagal bendrą deskriptorių ${ }^{17}$.

${ }^{16}$ EUROJOS projekte nagrinejjama 100 anketų. Manoma, kad jų visiškai pakanka pagrindiniams deskriptoriams išskirti.

17 Atkreiptinas dèmesys, kad tokiuose tyrimuose kognityvinei definicijai imami tik tie deskriptoriai, kurie sudaro daugiau kaip 1 procentą atsakymų, tačiau tuo atveju, kai net mažiau kaip procentas atsakymų yra reikšmingi kognityvinei definicijai, jie analizuojami ir ịtraukiami ị tyrimo rezultatus. 
1 lentelè

\begin{tabular}{|c|c|c|}
\hline Deskriptoriai & Apibūdinamieji teiginiai & $\begin{array}{c}\text { Kiekybinè } \\
\text { išraiška }\end{array}$ \\
\hline Sąjunga & $\begin{array}{l}\text { Europos Sajunga (27); ES (7); valstybiu sajunga (2); visu } \\
\text { Europos šaliu sajunga, kur nèra sienu ir yra daugybe ga- } \\
\text { limybiu keliauti (2); Europos Unija; Bendrija; mažesniu ir } \\
\text { didesniu šaliu susibürimas; šaliu sajunga; istoriškai susi- } \\
\text { klosčiusi žmoniu bendrija; nepriklausomas šalis vienijanti } \\
\text { sajunga; šaliu grupè; SSSR; sajungu kova; tautu sajunga; } \\
\text { žmoniu sajunga; netikras, mistifikuotas ir kartu akiplěšškai } \\
\text { įnirtingai ir neapgalvotai garbinamas konstruktas }\end{array}$ & $10,42 \%$ \\
\hline Žemynas & $\begin{array}{l}\text { žemynas (34); Europos žemynas (9); modernus, nuolat besi- } \\
\text { vystantis žemynas; gausiai apgyvendintas žemynas; Senasis } \\
\text { Žemynas; vieningas žemynas; pavyzdys kitiems pasaulio } \\
\text { žemynams; demokratija puoselèjantis žemynas }\end{array}$ & $10,21 \%$ \\
\hline Kultūra & 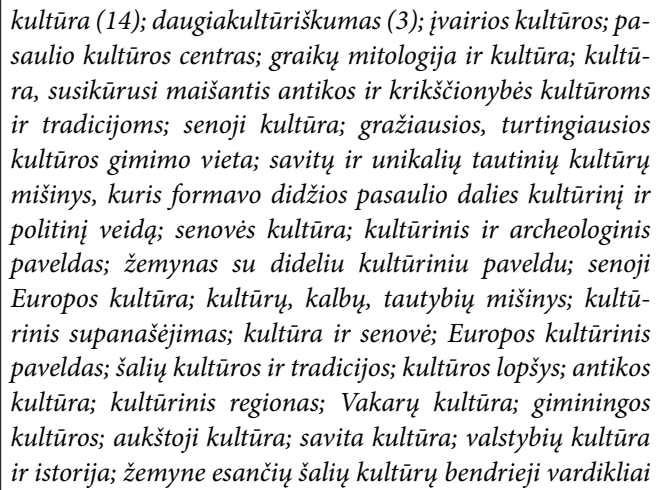 & $8,75 \%$ \\
\hline Valstybès, šalys & $\begin{array}{l}\text { Lietuva ir didinga jos istorija (6); daug šaliu (3); Lietuva (3); } \\
\text { šaliu vieningumas (2); kiekvienos šalies tapatybès išsaugoji- } \\
\text { mas; demokratinés valstybes; Vakaru valstybès; kaimynines } \\
\text { šalys; valstybiu bendradarbiavimas; valstybes ir ju sostines; } \\
\text { valstybių identiteto praradimas; valstybes; viena kontinen- } \\
\text { tinè valstybe; visos šalys yra unikalios ir turi savo identitetą; } \\
\text { valstybess, kurios save priskiria Europai, tiki Europos idèja } \\
\text { ir priklauso jai geografiškai; valstybès Europos žemyne; } \\
\text { Europos žemyno šalys; karalystes; šalis, kuri panaši i bata } \\
\text { (Italija); šalis, gaminanti puikias mašinas (Vokietija); šalis, } \\
\text { kupina aristokratiškumo (Anglija) }\end{array}$ & $6,46 \%$ \\
\hline
\end{tabular}




\begin{tabular}{|c|c|c|}
\hline Deskriptoriai & Apibūdinamieji teiginiai & $\begin{array}{l}\text { Kiekybinè } \\
\text { išraiška }\end{array}$ \\
\hline Istorija & $\begin{array}{l}\text { istorija (10); turtinga istorija (3); Europos istorija; senovès } \\
\text { istorija; sajunga, kuria vienija bendra bei įvairi istorija; se- } \\
\text { nové; panaši istorine praeitis; XVIII a. }\end{array}$ & $3,96 \%$ \\
\hline $\begin{array}{l}\text { Tradicijos ir } \\
\text { vertybès }\end{array}$ & $\begin{array}{l}\text { vertybès (3); tradicijos (3); senosios tradicijos (2); bendros } \\
\text { vertybès; tautos, vienijamos vakarietišku tradiciju bei verty- } \\
\text { biü; papročiai; įvairios tautos ir tradicijos; labai senos tradi- } \\
\text { cijos ir ju tęstinumas; senos tradicijos; vakarietišku tradiciju } \\
\text { ištakos; vertybiu sajunga; tikruju vertybiu puoselejimas; } \\
\text { daugybè šaliu su savo istorija ir išlaikytomis tradicijomis; } \\
\text { tradicijas gerbianti visuomene }\end{array}$ & $3,96 \%$ \\
\hline $\begin{array}{l}\text { Politinès } \\
\text { santvarkos ir } \\
\text { ideologija }\end{array}$ & $\begin{array}{l}\text { demokratija (9); fašizmas; komunizmas; nacionalumas; li- } \\
\text { beralumas; utopija; konservatizmas; pilietiškumas; monar- } \\
\text { chijos; biurokratija ir popierizmas }\end{array}$ & $3,75 \%$ \\
\hline Ekonomika & $\begin{array}{l}\text { euras (4); ekonomika (2); bendra valiuta (2); euro zona (2); } \\
\text { infliacija; ekonomikos augimas; aukšto BVP kontinentas; } \\
\text { viena valiuta; aukšta ekonomika; bendra ekonomika; koor- } \\
\text { dinuota rinkos ekonomika }\end{array}$ & $3,54 \%$ \\
\hline Tolerancija & tolerancija (9); lygybe (8) & $3,54 \%$ \\
\hline $\begin{array}{l}\text { Laisvas judè- } \\
\text { jimas }\end{array}$ & $\begin{array}{l}\text { galimybe laisvai keliauti po šalis (3); Šengeno erdvè (2); } \\
\text { laisvas judejimas (2); atviros sienos (2); kelionès (2); sieny } \\
\text { nebuvimas; nevaržomas judejimas; atvirumas }\end{array}$ & $2,92 \%$ \\
\hline $\begin{array}{l}\text { Geografinè } \\
\text { padètis }\end{array}$ & $\begin{array}{l}\text { geografija (7); žemynas nuo Pirènu pusiasalio iki Uralo } \\
\text { kalnų (2); atskyrimas nuo Amerikos, Australijos, Antarkti- } \\
\text { kos ir Afrikos žemynų; šalia Azijos; žemynas, kurị skalauja } \\
\text { Atlanto vandenynas; Viduržemio jūra }\end{array}$ & $2,71 \%$ \\
\hline Laisvè & $\begin{array}{l}\text { laisvé (8); nepriklausoma valstybé; nepriklausomybe; } \ddot{z} o- \\
\text { džio, spaudos, judèjimo laisvé }\end{array}$ & $2,29 \%$ \\
\hline $\begin{array}{l}\text { Bendradarbia- } \\
\text { vimas }\end{array}$ & $\begin{array}{l}\text { bendradarbiavimas (4); bendryste (3); bendradarbiavimas } \\
\text { ir geri tarpusavio santykiai (2); partneryste }\end{array}$ & $2,09 \%$ \\
\hline Architektūra & $\begin{array}{l}\text { architektūros ịvairové; graži architektūra; Eifelio bokštas; } \\
\text { architektūra; istoriniai pastatai ir vietos; nuostabiai gra- } \\
\text { žūs senamiesčiai, išskirtine Europos architektūra; senoji } \\
\text { architektūra; architektūrinis paveldas; Koliziejus; ìspūdingi } \\
\text { miestai }\end{array}$ & $2,09 \%$ \\
\hline
\end{tabular}




\begin{tabular}{|c|c|c|}
\hline Deskriptoriai & Apibūdinamieji teiginiai & $\begin{array}{l}\text { Kiekybinė } \\
\text { išraiška }\end{array}$ \\
\hline Tautos & $\begin{array}{l}\text { skirtingu tautu, kalbu ir tradiciju katilas (2); tautu puodas, } \\
\text { katilas; kiekvienos tautos indelis; tautiniai išskirtinumai; } \\
\text { begale skirtingu tautų; daugiatautiškumas; visos civilizuo- } \\
\text { tos Europos tautos, kurios nenori karo ir siekia taikos; tau- } \\
\text { tos, kurios siekia viena kitai padèti ịvairiu karu ar ekono- } \\
\text { miniu, politiniu katastrofu metu; daugiatautis kraštas, kur } \\
\text { kiekviena tauta turi savo valstybę su savom tradicijom ir } \\
\text { unikaliu mentalitetu }\end{array}$ & $2,09 \%$ \\
\hline Antika & $\begin{array}{l}\text { senoji Graikija ir Romos imperija (2); Atènu mokslas, Ro- } \\
\text { mos teisè ir Jeruzalès tikèjimas; antikos filosofai ir mąstyto- } \\
\text { jai; Romos teisé; Senoji Romos imperija; antikos laiku civili- } \\
\text { zacijos; krikščioniškas kontinentas su graiku demokratijos ir } \\
\text { romènu teisès pagrindu }\end{array}$ & $1,67 \%$ \\
\hline Teritorija & $\begin{array}{l}\text { geografinè teritorija (3); geografiškai apibrèžiamas darinys; } \\
\text { Europos žemé; Europos žemélapis; aiškiai apribota teritori- } \\
\text { ja; tiek geografiškai, tiek kultūriškai aiškiai atskirta erdve, } \\
\text { besidalijanti tam tikromis vertybèmis }\end{array}$ & $1,67 \%$ \\
\hline Vienybė & $\begin{array}{l}\text { vienybe (6); tai, kas jungia europiečius } i \text { viena visumą; vie- } \\
\text { ninga bendruomené }\end{array}$ & $1,67 \%$ \\
\hline Civilizacija & $\begin{array}{l}\text { Vakaru civilizacijos lopšys (2); Europos civilizacija, kuria } \\
\text { išaugino krikščioniška tradicija; civilizacijos ištakos; civili- } \\
\text { zacijos gimimas; Vakaru civilizacijos paminklai; civilizaci- } \\
\text { jos židinys }\end{array}$ & $1,46 \%$ \\
\hline Taika & $\begin{array}{l}\text { taika (4); taika ir darna žemyne; be sienu ir apribojimu, be } \\
\text { konfliktu, be kovų; taiki, vieninga, saugi erdvé }\end{array}$ & $1,46 \%$ \\
\hline Galimybès & $\begin{array}{l}\text { galimybès (4); darbo galimybès įvairiose Europos šalyse; } \\
\text { langas j̣ didesnę, šviesesnę erdvę }\end{array}$ & $1,25 \%$ \\
\hline $\begin{array}{l}\text { Konfliktai ir } \\
\text { grèsmès }\end{array}$ & $\begin{array}{l}\text { karai, diktatoriai, sukilimai, revoliucijos (2); karas Ukrai- } \\
\text { noje; du pasauliniai karai; karai, kurie žemyną niokoja jau } \\
\text { tūkstančius metu; naujos grèsmès ir iššūkiai iš islamiškojo } \\
\text { pasaulio ir Rusijos }\end{array}$ & $1,25 \%$ \\
\hline $\begin{array}{c}\text { Istorinès } \\
\text { asmenybès, jų } \\
\text { darbai }\end{array}$ & $\begin{array}{l}\text { Gutenbergo spausdinimo presas (2); Mocarto simfonijos; } \\
\text { Mocartas; Haidnas; Bethovenas }\end{array}$ & $1,25 \%$ \\
\hline Išsilavinimas & $\begin{array}{l}\text { išsilavinę, garbingi žmonès (2); Bolonijos universitetas; ta- } \\
\text { lentingi, išsilavinę žmonès; aukštas išsilavinimo lygis; išsi- } \\
\text { lavinimas }\end{array}$ & $1,25 \%$ \\
\hline
\end{tabular}




\begin{tabular}{|c|c|c|}
\hline Deskriptoriai & Apibūdinamieji teiginiai & $\begin{array}{l}\text { Kiekybinė } \\
\text { išraiška }\end{array}$ \\
\hline Draugiškumas & $\begin{array}{l}\text { draugiškumas (2); draugyste; vieta draugiškai gyventi, gerb- } \\
\text { ti, saugoti ir skleisti savo kultūrą; draugiškas tautu ryšiu } \\
\text { palaikymas, vienas kito rèmimas }\end{array}$ & $1,04 \%$ \\
\hline Gerovè & gerovè (4); žmogaus ir valstybés padeties gerinimas & $1,04 \%$ \\
\hline Išsivystymas & pažanga (2); išsivystymas; tobulejimas; progresas & $1,04 \%$ \\
\hline Mokslas & $\begin{array}{l}\text { mokslas (2); mokslo ir technologiju centras; mokslo ir meno } \\
\text { progresas; mokslo pasiekimai }\end{array}$ & $1,04 \%$ \\
\hline Namai & namai (4); saugumas & $1,04 \%$ \\
\hline Religija & $\begin{array}{l}\text { Europa primena kažkokią dievybę; Šventasis Raštas; religija } \\
\text { ir religines vertybès; vieta, kur apibrèžiamos ir nustatomos } \\
\text { etines normos; krikščionybe }\end{array}$ & $1,04 \%$ \\
\hline Žmonès & $\begin{array}{l}\text { daug susivienijusiu gyventojų ir jokių emigrantų iš kitu že- } \\
\text { mynų; europiečiai; autochtoniniu europiečiu kontinentas; } \\
\text { žmones, kurie gyvena Europoje; jungtis tarp Europoje gy- } \\
\text { venančių žmonių }\end{array}$ & $1,04 \%$ \\
\hline Mitologija & $\begin{array}{l}\text { Europa ir mitas apie ja (2); antikos mitai; senoves graiku } \\
\text { mitologija }\end{array}$ & $0,83 \%$ \\
\hline $\begin{array}{l}\text { Prieštaringai } \\
\text { vertinamos } \\
\text { asmenybės }\end{array}$ & V. Putinas (3); Adolfas Hitleris & $0,83 \%$ \\
\hline
\end{tabular}

Iš pateiktų duomenų matyti, kad Europos Sąjunga yra didžiausias deskriptorius. Atsižvelgiant ị tai, kas buvo pasakyta kultūrinès apžvalgos skyriuje, galima matyti, kad Europoje dabar gajos idejjos - tolerancija, daugiakultūriškumas, lygybė - Lietuvai visada buvo svarbios, nepaisant požiūrio, kad Lietuva ir Europa yra tam tikros skirtybès. Tai nekeičia minties, kad kultūros ir idejiniai panašumai svarbiausi yra tada, kai dèl jų ilgai kovota.

Jau buvo minèta, kad lietuvių kalbos sisteminiuose žodynuose $E u$ ropa nebuvo aprašyta, nepateikti jos sinonimai, antonimai. Tačiau iš apklausų matyti, kad apklaustieji gana aiškiai tokius dalykus skiria. Turbūt geriausiai Europos sinonimus apibūdina sakinys: „Europos sinonimas yra draugija“. Akivaizdu, kad kaip Europos sinonimai gali būti Europos Sajunga, Europos žemynas, demokratinès vertybès, daugiakultūriškumas ir t. t. Bet greičiausiai tinkamiausias sinonimas būtų Vakarai. 
Kalbant apie antonimus irgi reikètų pradèti nuo sakinio, paimto iš vieno apklausos atsakymo. Šis sakinys puikiai atspindi dabartinị žmonių požiūrị: „Europa tai savotiška antitezè ne tik viskam, kas driekiasi į Rytus, bet ir Amerikai“. Iš jo ir sinonimų galima daryti prielaidą, kad Europos antonimai yra: bet kuris kitas žemynas, nedemokratinès valstybès, europietišku vertybių nepripažistančios valstybès ir pan. Šioje vietoje idomus Amerikos kaip priešpriešos Europai nurodymas, tai gana naujas požiūris. Lietuvių kalboje esama eufemizmų, kur Amerika turi kažko aukštesnio, tam tikros siekiamybès, o gal ir mistinę semą. Tai eufemizmai, kuriais kitaip nusakomas gimimas (iš Amerikos parvažiuoti, amerikonas atplaukè) ir mirtis (i Ameriką / juodają Amerika važiuoti). Greičiausiai šie eufemizmai atsirado XIX a. ir yra sietini su pirmąja emigracijos ị Ameriką banga. Todèl galima suprasti, kodèl Amerika ir šiais laikais suvokiama kaip šiokia tokia priešybė Europai. XIX a. Amerika dèl socialinių aspektų buvo tapusi geresnio, laimingesnio gyvenimo simboliu, o dabar šią vietą užèmė Europos Sąjunga ir joje esančios ekonomiškai stipresnès valstybès.

\section{Atskirų diskursų analizė}

Kaip minèta kultūros apžvalgoje, Europa lietuvių tekstuose pasirodo palyginti vèlai. Šioje tyrimo dalyje pateikta medžiaga, rinkta iš XIX ir XX a. tekstų ir šių dienų spaudos. Be ịprasto geografinio konteksto, Europa dažniausiai minima politiniame diskurse, ypač po Lietuvos įstojimo ị Europos Sąjungą $2004 \mathrm{~m}$. Ir nors „Europa - pernelyg bendra sąvoka ir dèl to atrodo beprasmiška“ (Arūnas Spraunius, „Europos saulèlydis ar saulèlydis Europoje?“, Delfi.lt), „Pakapsčius giliau, paaiškejja, kad glaudesnè Europa reiškia daugybę dalykų labai dideliam žmonių skaičiui “ (Alina Bargaoanu, „ES ateitis: Jungtinès Europos Valstijos ar Disneilendas turistams iš Kinijos?", Delfi.lt), vis dèlto atskiruose diskursuose galima jžvelgti Europos suvokimą. Tekstų duomenys iš esmès patvirtina apklausų duomenis. Daugiausia apie Europą kalbama kaip apie Europos Sąjungą, žemyną, kultūros lopši, istorinį vienetą, tam tikrų vertybių ištakas. 
Pirmiausia aptartinas politinis diskursas. Jame ryškios kelios pozicijos: proeuropietiška, antieuropietiška, neutrali. Politiniuose tekstuose Europa dažnai pateikiama kaip demokratijos principais grindžiamas vienetas, pavyzdžiui:

A. Paulauskas: „Didžioji Europa“ - tai kaimynų solidarumas.“ (Delfi.lt.)

V. Landsbergis: „Pastarieji keleri metai ir ypač Lietuvos pirmininkavimas Europos Sąjungai, Europos vadovų viršūnių susitikimas Vilniuje išryškino ir sustatẻ labai svarbius taškus, kurie mums buvo žinomi, bet dabar tapo aiškūs labai plačiai. Europa bunda, Europa susivokè tikrovejje kur kas geriau negu prieš keletą metų. O tie taškai yra paprasti - dabartine Rusija atmeta demokratiją, atmeta Europa $<\ldots>$." (Delfi.lt.)

„Europos dvasia skleidèsi per liberaliąją humanistinę asmens orumo moralę, žmogaus teises, jomis grịstu teisiniu reguliavimu ir joms ginti steigiamomis institucijomis, kurias vainikavo Strasbūro teismas." (Vladimiras Laučius, „Europai stinga noro grịsti gèrị galia“, Delfi.lt.)

„Toks pakylètas pasididžiavimas - štai mes jau tikrai Europa.“ (Ginta Gaivenytė, „Eurobendrystė su pakelta arklio uodega“, Lrytas.lt.)

„Nes Europa - tai didžiulëje ịtampoje tarp žinojimo ir tikejjimo, o sykiu ir tarp galios ir tikejjimo istoriškai išsiskleidusi save pagrindžiančio ir koreguojančio politinio bei moralinio individo laisvè.“" (Leonidas Donskis, „Kas vienija ES?“, Delfi.lt.)

„Trumpai kalbant, „Europos“ sąvokoje esama per daug išimčių, o pačioje Europoje - per daug svetimųjų, turinčių tuos pačius bruožus kaip ir europiečiai. Galima sakyti, kad žodis „Europa“ yra žodžių „pakantus“, „civilizuotas“ ir „šiuolaikinis“ sinonimas, bet taip pat teks pripažinti, kad daugelis „europiečių“ tokie nèra.“ (Arūnas Spraunius, „Europos saulèlydis ar saulèlydis Europoje?", Delfi.lt.) 
Paskutinis teksto pavyzdys puikiai atspindi didelès politinio diskurso tekstų dalies esmę - Europa, nors vertintina teigiamai, vis dèlto lietuviams yra kiek svetima. Tai nereiškia, kad Lietuvoje yra teigiamos kitos vertybès negu „likusioje Europoje“. Lietuva dèl savo geografinès padèties ir kaimyninių šalių visą laiką buvo kultūrų sankryžoje, tolerancija jai nesvetima. Tačiau žiniasklaidoje Europa dažnai pateikiama kaip ES sinonimas ir, matyt, dèl gana vèlyvo Lietuvos ịstojimo atsiradęs kiek neigiamas požiūris $\mathfrak{i}$ ją, noras nesitapatinti, atsiribojimas nuo jos ar prielaida, kad kitiems Europos gyventojams lietuviai nèra savi:

„Nors Lietuva ir dar 9 Vidurio ir Rytų Europos valstybės jau priklauso Europos Sąungai, nemažai daliai vakariečių Europa - tai tik Vakarų Europa.“ (Palmyra Krupenkaitė, „Nuomonè. Kiek Europoje Europų?“, Delfi.lt.)

„Be abejo, Europa - tai ne ES.“ (Arūnas Spraunius, „Europos saulèlydis ar saulèlydis Europoje?", Delfi.lt.)

„Kad ir kiek kalbètume, kad Europa - tai mes patys, per visą stojimo ị ES laikotarpị, kai Lietuvos ịstatymai ir poịstatyminiai aktai buvo derinami prie šios bendrijos reikalavimų, ir pirmąjị buvimo ES dešimtmetị, kai mūsų politikai pamėgo atsakomybę už nepopuliarius sprendimus suversti Europos nustatytai tvarkai, susiformavo kažkoks anapusinès antgamtinès mūsų gyvenimus tvarkančios jègos įvaizdis." (Romas Sadauskas-Kvietkevičius, „Žiemos ir vasaros laiko likimą turi spręsti visa tauta“, Delfi.lt.)

„Niekas kol kas nenori ES mesti, tačiau niekas jos nebemyli - Europa tampa nebe tikslas, o naudos gavimo instrumentas, Europa - atpirkimo ožys, tampantis visų krizių pirmine priežastimi.“ (E. Vareikis, „Nesutapusių charakterių Sąjunga ir Naujoji Žečpospolita“, Delfi.lt.)

„Mes esame Europos viduryje ir visada būsime kitokie, nei yra Vakarai.“ (Gabrielè Valaitytè, „R. Ozolas: nesame protingiausi, geriausi, gražiausi“, Delfi.lt.) 
Kitaip tariant, politiniame diskurse esama nuomonès, kad Europa yra padalyta:

„Europa, kurią simbolizavo Roma, galiausiai pasuko skirtingais keliais - Vakarų bei Rytų. Kuri Europa - vakarinè ar rytinė yra tikra, verta pasiginčyti.“ (E. Vareikis, „Kodèl Europą sukūrè Karolis Didysis, o ne Vytautas Didysis?", Delfi.lt.)

„Galbūt ne prie fizinès „geležinès uždangos“, bet prie tam tikros uždangos, skiriančios laisvą Europą nuo mažiau laisvos Europos.“ (Monika Garbačiauskaitè-Budrienè specialiai DELFI iš Vašingtono, „Paaiškino, ko iš Europos nori V. Putinas“, Delfi.lt.)

„Po komunizmo žlugimo praejjo daugiau nei du dešimtmečiai, tačiau Europa vis dar išlieka aiškiai padalinta ị dvi dalis.“ (Lrytas.lt.)

Atsiribojimą nuo Europos, tiksliau - jausmą, kad posovietinès valstybès niekada nebus lygiavertès Europos partnerès, galima vadinti neutralia pozicija. Dalyje politinio diskurso tekstų atsispindi visiškai neigiamas požiūris:

„Europos tautos jau mato, kad kryptinga „tolerancija“, o iš esmès netolerancija religinėms, tautinėms, kultūrinèms tradicijoms, pasiekè pavojingą ribą.“ (Vytautas Visockas, „Sekmadieniniai pamąstymai. O supratimo, kodèl taip atsitiko, ar padaugejo?", Slaptai.lt.)

„Jis yra viešai pareiškęs, kad Europa - tai skęstantis laivas, kuriam vadovauja gejjai“ (Algimantas Čekuolis, „Vladimiras Putinas aštrina adatą", Slaptai.lt.)

„Vakarų Europoje vyksta kultūrinis karas prieš gyvybès kultūrą, šeimą ir kitas krikščioniškąsias vertybes, kurios laikomos „atgyvena“““ (Slaptai.lt.)

Žmonių komentarai po žiniasklaidoje esančiais tekstais dar kartą atspindi Europos prieštaringumą. Jie yra dalies visuomenès nuomo- 
nè. Pastaruoju metu matyti tendencija vartoti naujadarą "gèjropa“: „Supuvusi Gejjropa“ (komentaras iš Respublika.lt); „Myliu aš geiropą, patinka gyvent, kur gyvenu, keliauti, kur noriu, turèti belekiek galimybių susirasti darbą visoj Europoj“ (komentaras iš Vz.lt); „Valio, nèra lito, nèra Lietuvos, tegyvoja Geiropa“ (komentaras iš Ve.lt); „Bet Geiropa mus okupavo be tankų ir suteikè partinei mafijai rojų“ (komentaras iš Respublika.lt); „Tau ir i tave panašiems „tolerastams“ tèvynè tai "geiropa“ (komentaras iš Banga.balsas.lt). Tai Rusijoje plačiai vartojamas neigiamas Europos apibūdinimas, todèl neatmestina, kad tokie komentarai gali atspindèti tik labai mažos visuomenès dalies nuomonę.

Šiandienis neigiamas požiūris ị Europą politiniame kontekste gali būti lyginamas su sovietinejje Lietuvoje išspausdintų tekstų ištraukomis: „Visos Europos kapitalistai ištiesė letenas ị pasaulio dalị, kurioje gyvena šimtai milijonų žmonių, į Aziją“ rš.; „Neramus, irus ir ligūstas Europos buržuazijos gyvenimas“ rš.; „Ir štai dabar Europos kapitalistų godžios letenos išsitiesè i Kiniją “ rš. Šias ir prieš tai pateiktąsias tekstų ištraukas skiria keli dešimtmečiai, todèl nevienodos ir Europai priskiriamos blogybès. Anksčiau Europa buvo apibūdinama kaip „buržuazinë“, šiandien ji priešpiešinama tokioms vertybèms kaip šeima, tradicijos, patriotizmas. Būtina pabrèžti, kad po 2014-2015 m. îvykių Ukrainoje euroskeptikų žymiai sumažėjo ir paprastai Europa visuomenès vertinama kaip tolerancijos, daugiakultūriškumo, saugumo užuovèja, gebanti savyje sujungti daug ir įvairių žmonių:

„Europa tikrai gali būti daugiakultūriška“ (Paulius Gritènas, „L. Donskis: Jau metas radikalų islamizmą prilyginti fašizmui“, Lrytas.lt.)

Be abejo, ir politiniame diskurse esama geografinio aspekto. Iprasta, kad Europa čia suvokiama kaip žemynas, pavyzdžiui: „Anksčiau nelegalūs migrantai Europos pakrantes bandydavo pasiekti nedideliais laiveliais ar plaustais" (Alkas.lt.)

Nuo politinio diskurso verta pereiti prie istorinio. Pastarasis iš dalies paaiškina, kodèl šiandienių lietuvių pasąmonèje glūdi atsiribojimas nuo 
kitų europiečių - istoriniai tekstai atspindi aiškų suvokimą, kad ten yra Vakarų Europa, o čia - Lietuva, tik Europos dalis, bet ne Vakarų:

„Žalgirio pergalè Vakarų Europos akyse nepaprastai iškèlè Lietuvos ir Lenkijos prestižą" rš.

„Gediminas kvietė ị Lietuvą amatininkus iš Vakarų Europos kraštų ir davè jiems įvairių privilegijų“ MLTEI52.

„Ordino agentai, popiežiaus ir imperatoriaus remiami, Vakarų Europoje skelbè, jog Lietuva tebesanti pagoniška, jog lietuviai esą tikri saracènai bei krikščionybès priešai ir t. t." LII138.

„Lietuva paskutinė Europoje buvo sukrikščioninta“ rš.

Bet dažniausiai Europa istoriniame diskurse iškyla kaip regionas, sietinas su tam tikrais istoriniais įvykiais, retesniais atvejais ji personifikuojama:

„III tūkstantmetyje pr. m. e. visa Europa jau plačiai pažino akmeninius įrankius, gamintus šlifavimo būdu“ rš.

„Po pirmojo pasaulinio karo visą laiką Europa sėdejjo ant parako statinès, ir ji anksčiau ar vèliau turejjo sprogti“ $\mathrm{K}$. Bor.

Istorijos tekstai patys savaime turi būti objektyvūs, todèl ir Europa juose apibūdinama neutraliai, tai yra istoriniame diskurse jai nepriskiriama jokių neigiamų ar teigiamų bruožų, ji figūruoja kaip istorinis vienetas.

Kitokios nuotaikos vyrauja kultūriniame diskurse. Jau minèta, kad politiniame diskurse Europa daugiausia tapatinama su ES (tą rodo ir anketos) ir jos priimamais sprendimais, kurie gali būti vertinami prieštaringai. O kultūriniame diskurse Europa beveik visais atvejais pasirodo kaip teigiamas, siektinas idealas, kas savaime suprantama, nes kultūra vargu ar gali būti vertinama neigiamai remiantis objektyviais kriterijais. Itin retais atvejais Europai priskiriama menkavertẻ kultūra, tačiau tai būdingiau ideologiniams tekstams: „Vakarų Europos pūvančios kultūros garbintojai“ sp.

Kitais atvejais kultūriniame diskurse Europa yra senovinių tradicijų tąsa, grožis, vertybès, laisvè, vienybė ir, be abejo, civilizacijos lopšys:

„Europos kultūros diegus tebekalèjo stiprios romėnų kultūros tradicijos" rš. 
„Perèjo ị Europos gražybes ir stebėtinumus“ Vaižg.

„Europos poezija, proza, dramaturgija ịsitvirtino kaip pagrindinis vertybių matas ir "pasaulinès literatūros“ sinonimas“ rš.

„Reikètų prisiminti, kad poetas ir rašytojas, literatūros istorikas, filosofas, vertėjas, kovotojas už laisvą žodị ir laisvą mintị, bendros Europos idejos puoselètojas, Lietuvos-Lenkijos santykių vizionierius, Lietuvos Didžiosios Kunigaikštystės tradicijos aristokratas Česlovas Milošas kol kas yra vienintelis Nobelio premijos literatūros srityje laureatas, kilęs iš Lietuvos, joje gyvenęs.“ (Rūta Švedienè, „Ruošiamasi paminèti 103-ąji Česlovo Milošo gimtadienị“, Alkas.lt.)

„Vydūnui ypatingas dėmesys buvo skirtas ir Europos dienų proga Detmolde surengtoje konferencijoje „Europos idejja literatūroje ir kalboje“, kurios viename iš trijų pranešimų (jị skaitė Vydūno draugijos garbės pirmininkas Vacys Bagdonavičius), mąstytojas pristatytas kaip vieningos Europos idèjos pirmtakas.“ (Vacys Bagdonavičius, „Vydūno idèjinis palikimas Europai“, Alkas.lt.)

„Tačiau Europa tapo senųjų civilizacijų lopšiu.“ (Delfi.lt.)

Vienas iškiliausių lietuvių poetų Maironis savo kūryboje mini Europą kontekste, kuris lenkia laiką - Europos kaip namų, sąjungos, daugiatautès vietos, kur vyrauja taika, suvokimas jo eilèraščiuose ypač ryškus (Jonaitis 1994): „Ir gal laikai - nebtolimi, / Kad bus Europoj renkami / Didžios respublikos atstovai / I bendrą seimą nuo tautų, / Visų be skyriaus pašauktų, / Išnykus tarptautinei kovai“ (ištrauka iš poemos „Mūsų vargai“).

Paminėtina ir mitologijoje iškylanti Europa, nes šis pavadinimas siejamas ne tik su žemynu ar politiniu dariniu: „Europa - graži princesė, kurią pagrobė Dzeusas, atgabeno ị Kretą, ten ji pagimdè tris sūnus Miną, Radamantą ir Sarpedoną, kurie tapo povandeninio pasaulio teisejjais“ (Delfi.lt); Europé valdė pakalinę dalį Peonijos, kurią savo vardu Europa vadino“ S. Dauk. 
Mokslininkų, kultūros veikèjų tekstuose Europa netiesiogiai, bet vis dèlto atskiriama nuo kitų žemynų, gali būti suvokta kaip jų antonimas: „Iš Amerikos pirmiausiai ing Europą parvežè taboką, roputes, nasturtas, saulègrąžas"I. Kaip ir politiniame diskurse, čia Europa iškyla kaip vienas žemynas: „Klykuolè gyvena Europos ir Azijos šiaurinèje dalyje“ T. Ivan.

Remiantis tekstų analize galima teigti, kad politikos diskurse Europos sinonimai yra solidarumas, demokratija, žmogaus teisès, galia, laisvė, taika, saugumas, universalumas, pakantumas, civilizacija, šiuolaikiškumas, Vakarų Europa, Europos Sąunga. Neigiamame kontekste Europa vadinama atpirkimo ožiu, neaiškia antgamtine jèga, skęstančiu laivu, Gejjropa, ją apibūdina žodis netolerancija. Europos antonimais gali būti Rytų Europa, mažiau laisva Europa.

Istoriniame kontekste Europos sinonimai yra Vakarų Europa, visa Europa, antonimas - Rytų Europa.

Kultūriniame diskurse Europos sinonimais tampa daugiakultūriškumas, daugiakalbystè, idejja, senų tradicijų ir civilizacijos lopšys, grožis, vertybès, laisvè, vienybė. Neigiamame kontekste vartojamas antonimas supuvusi kultūra.

\section{Apibendrinimas}

Atsižvelgiant $\mathfrak{i}$ apklausų ir tekstų duomenis, darytina išvada, kad Europa šiuolaikiniams lietuviams daugiausia asocijuojasi su politikos sfera: pirmiausia tai yra Europos Sąunga, vienijanti įvairias laisvas valstybes ir žmones; kurioje vyrauja taika, saugumas, teisingumas; grindžiama demokratija, humanistinèmis idejomis; kurią netgi galima suvokti kaip vieną didelę, vieningą valstybę; kartais tapatinama tik su Vakarų Europa.

Antroje vietoje yra Europos kaip geografijos reiškinio suvokimas: tai yra žemynas; šalia Azijos; ir atskirtas nuo kitų žemynų: Amerikos, Australijos, Antarktidos, Afrikos; besiplečiantis nuo Pirènų pusiasalio iki Uralo kalnų. 
Europa lietuviams asocijuojasi su kultūros sfera, jiems tai: turtinga, sena kultūra arba ịvairių kultūrų, tautų, kalbų, papročių simbiozè; turinti dideli paveldą; gausias ir senas tradicijas, ịvairią architektūrą; prisimenama ir princese Europa, mitologijos veikèja.

Taip pat Europa suvokiama kaip buitinè gerovè: tai civilizacijos lopšys; turintis bendrą valiutą ir ekonomiką; atveriantis dideles galimybes.

Lietuviams aktuali socialinė sfera. Europa jiems yra vieninga bendruomené; grindžiama tolerancija ir lygybe; bendradarbiavimu.

Didelei daliai lietuvių Europa pirmiausia siejama su jos istorija, kuri paprastai apibūdinama kaip turtinga.

Be apklausų ir tekstų duomenų bendrumų, esama ir skirtumų. Idomu pastebėti, kad skirtumų atsiranda, kai prasideda anksčiau minètų sutapimų vertinimas. Vieni iš ryškesnių skirtumų yra: Vakarų Europos nenoras pripažinti posovietinio bloko valstybių kaip sau lygiaverčių, taip pat Vakarų Europos nenoras laikytis tradicinių vertybių ir savo „vienintelių teisingų“ vertybių primetimas kitiems. Pagrindinis skirtumas tarp apklausų ir tekstų - apklausų dalyviams labai svarbu identiteto, kultūros išsaugojimas, o tekstuose tokios mintys iškeliamos tik antieuropietiškame kontekste.

Apklausose pastebimas gyvesnis reagavimas i pastaruosius Europoje vykstančius ịvykius, kurie žiniasklaidoje nušviečiami, apmąstomi keliomis dienomis vèliau, nei žmonès susipažista su informacija. Apklausose buvo rasta ir antiimigracinių (ypač iš Afrikos ir islamo kraštų) ir antiislamiškų idejjų. Taip pat gana ryškus karo Ukrainoje šešèlis, kurị žiniasklaida stengiasi sumažinti iki konflikto lygio.

Lyginant apklausas ir tekstų duomenis išryškejjo gana ịdomi priešpriešų grupé: Lietuva nelygu Vakarų Europa ir Lietuva nelygu Rytų Europa („Mes esame Europos viduryje ir visada būsime kitokie, nei yra Vakarai“ (Gabrielè Valaitytè, „R. Ozolas: nesame protingiausi, geriausi, gražiausi“, Delfi.lt)). Tokių minčių galima rasti ir tekstuose, ir studentų atsakymuose. Greičiausiai šioms priešpriešoms kelią grindžia gana gyva istorinè ir kultūrinè atmintis, jau buvo minèta, kad Lietuva istoriškai ir 
kultūriškai požiūrị i pasaulị perèmẻ iš skirtingų kultūrų. Iš esmės Lietuvoje susiduria ir Vakarų, ir Rytų, ir Šiaurès kultūros, dẻl to gana akivaizdus ir suvokimas, kad nesame nei Rytų, nei Vakarų Europa.

\title{
Kognityvinè definicija
}

Kaip matyti, lietuvių Europos suvokimą formuoja istorinė atmintis, literatūra, mokykla, bet didžiausią ịtaką šiuolaikiniam suvokimui daro žiniasklaida. Kadangi lietuvių kalboje sisteminių žinių apie Europa beveik nèra, iš studentų atsakymų ir tekstų lyginimo lietuvių Europos kognityvinè definicija galètų būti tokia:

Europa - tai esantis žemyne, besidriekiančiame nuo Pirènų pusiasalio iki Uralo kalnų, civilizacijos lopšys su turtinga istorija, ịvairių kultūrų, tautų, kalbų, papročių simbioze, gausiu paveldu, ịvairia architektūra, vieninga bendruomene, grindžiama tolerancija ir lygybe, bendradarbiavimu, demokratija, humanistinėmis idejjomis, kurią netgi galima suvokti kaip vieną didelę valstybę, kurioje vyrauja taika, saugumas, teisingumas, ir vienijančią ịvairias laisvas valstybes ir žmones, turinčią bendrą valiutą ir ekonomiką, atveriančią dideles galimybes.

\section{Šaltiniai}

\author{
Alkas.lt \\ Balsas.lt \\ Delfi.lt \\ Lkz.lt \\ Lrytas.lt \\ Respublika.lt \\ Slaptai.lt \\ Ve.lt \\ Vz.lt
}




\section{Santrumpos}

I - Laurynas Ivinskis

K. Bor - Kazys Boruta

Kp - Kupiškis.

Kt - Keturvalakiai, Vilkaviškio r.

L - Lietuviškos ir angliškos kalbų žodynas. Sutaise Antanas Lalis. Trečias, iš naujo taisytas ir gausiai papildytas, spaudimas. Chicago 1915

MLTE - Mažoji lietuviškoji tarybinė enciklopedija, t. I-III. Lietuvos TSR Mokslų akademija. Vilnius, 1966-1971

rš. - vertimų ir šiaip mažiau teišsiskiriančių raštų žodis ar sakinys S. Dauk - Simonas Daukantas

sp - spaudos žodis ar sakinys

T. Ivan - Tadas Ivanauskas

Vaižg. - Vaižgantas (Juozas Tumas)

\section{Literatūra}

Augustyniak, U. Wielokulturowość Wielkiego Księstwa Litewskiego i idea tolerancji, a praktyka stosunków międzywyznaniowych w XVI-XVIII. Lietuvos Didžiosios Kunigaikštijos tradicija ir tautiniai naratyvai. Vilnius, 2009.

Bairašauskaitè, T. Vietinis komponentas sociokultūrinès tapatybès konstrukcijose (istoriografinis kontekstas). Lietuvos Didžiosios Kunigaikštijos tradicija ir tautiniai naratyvai. Vilnius, 2009.

Bartmiński, J., Tokarski, R. Językowy obraz świata i spójność tekstu. Teoria tekstu. Wrocław, 1986.

Bartmiński, J. Czym zajmuje sie etnolingwistyka. Akcent. Wrocław, 1986, Nr. 4(26).

Bartmiński, J. Językowe podstawy obrazu świata. Lublin, 2007.

Gudavičius, A. Etnolingvistika. Šiauliai, 2009. 
Gudavičius, E. Lietuvos istorija. Vilnius, 1999.

Gudavičius, E. Tautinès lietuvių savimonès lygis XIV a. pabaigoje. Lietuvos Didžiosios Kunigaikštijos tradicija ir paveldo „dalybos“. Vilnius, 2008.

Jonaitis, M. Poetas ir visuomene XIX-XX amžių sankirtose. Klaipèda, 1994.

Jovaišas, A. Literatūra rusėnų kalba. Lietuvių literatūros istorija XIII-XVIII amžiuje. Vilnius, 2003.

Potašenko, G. Istorijos kultūra šiuolaikinèje Lietuvoje: daugiakultūriškumo samprata visuomenejje ir Lietuvos Didžiosios Kunigaikštijos tyrimuose. Lietuvos Didžiosios Kunigaikštijos tradicija ir tautiniai naratyvai. Vilnius, 2009.

Rudaitienè, V. Žodžiai su prepoziciniais nelietuviškos kilmès dèmenimis. Lituanistica. 2001, Nr. 2(46).

Survilaitè, J. Atsirèmus ị platų Europos žemėlapi. 2014. Prieiga per internetą: www.bernardinai.lt

Temčinas, S. Lietuvos Didžiosios Kunigaikštijos rusėniškoji literatūra kaip kultūrinès integracijos modelis. Lietuvos Didžiosios Kunigaikštijos tradicija ir tautiniai naratyvai. Vilnius, 2009. 


\title{
CONCEPT OF EUROPE IN CONSCIOUSNESS OF THE LITHUANIANS
}

\author{
Marius Smetona
}

\section{Summary}

Keywords: cognitive definition; discourse; concept; Europe; survey; culture.

Specific studies on the concept of Europe in Lithuanian are largely absent. The few studies that can be found in relation to the subject are a linguistic article by V. Rudaitienè and a book by N. Putinaite "Trys lietuviškos Europos. Tauta, Europa, ES dabartineje tapatybeje" (Three Lithuanian Europes: the Nation, Europe, the EU in Modern Identity) in which the author addresses the development of Lithuanians' European identity from the perspectives of culture, philosophy and political science. It is therefore impossible to formulate what Europe is to each Lithuanian and thus a separate study needs to be conducted to address this question.

Based on the data obtained from surveys and texts, a conclusion can be drawn that contemporary Lithuanians mostly associate Europe with the field of politics, with a geographical phenomenon, culture, household welfare, social sphere, and history. Respondents also emphasise the aspects of ideology and the nation, whereas the military or religion are virtually never referred to. Apart from similarities in survey and textual data, there are differences when it comes to the assessment of the above-mentioned unanimities.

Lithuanians' perceptions of Europe are shaped by historical memory, literature, and schools, however, the greatest role in the contemporary conception of Europe is played by mass media. The acquired data and its analysis leads to the conclusion that for Lithuanians Europe is a cradle of civilisation that geographically stretches from the Iberian Peninsula to the Ural Mountains and that is defined by a rich history, a simbiosos of a different cultures, nations, languages and customs, rich heritage, diverse architecture, a united community based on tolerance and equality, cooperation, democracy, and humanistic ideas. Europe can even be perceived as one large state where peace, security and justice prevail, a state that unites various independent countries and people, shares common currency and economy, and provides great oppoetunities.

Iteikta 2016 m. sausio $21 d$. 